\title{
False Penile Fracture: Case Series and Literature Review
}

\section{Yalancı Penil Fraktür: Olgu Serisi ve Literatürün Gözden Geçirilmesi}

\author{
Deniz Noyan Ozlu' ${ }^{1}$, Kamil Gokhan Seker² $₫$, Emre Sam³ ${ }^{3}$, Yusuf Arikan'®,

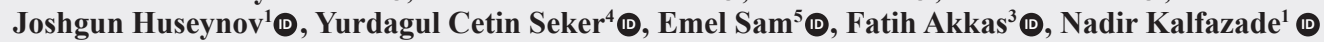

\author{
${ }^{1}$ Department of Urology, University of Health Sciences, Dr. Sadi Konuk Training and Research Hospital, Istanbul, Turkey \\ ${ }^{2}$ Department of Urology, Mus State Hospital, Mus, Turkey \\ ${ }^{3}$ Department of Urology, University of Health Sciences, Regional Training and Research Hospital, Erzurum, Turkey \\ ${ }^{4}$ Department of Emergency Medicine, Mus State Hospital, Mus, Turkey \\ ${ }^{5}$ Department of Emergency Medicine, University of Health Sciences, Regional Training and Research Hospital, Erzurum, Turkey
}

Cite as: Ozlu DN, Seker KG, Sam E, Arikan Y, Huseynov J, Seker YC, Sam E, Akkas F, Kalfazade N. False penile fracture: case series and literature review. Grand J Urol 2021;1(1):9-13.

Submission date: 13 December 2020

Acceptance date: 22 December 2020

Online first: 22 December 2020

Publication date: 20 January 2021

Corresponding Author: Deniz Noyan Ozlu / University of Health Sciences, Dr. Sadi Konuk Training and Research Hospital, Department of Urology, Bakirkoy, Istanbul, Turkey noyanozlu@hotmail.com ORCID: 0000-0003-2435-5482

\begin{abstract}
Objective: Penile fracture is one of the urological emergencies that require early surgical intervention. False penile fracture, on the other hand, is a condition that presents with similar clinical features and can be treated conservatively. In this study, in the light of the literature, it was aimed to present the clinical and operative results of 8 patients who were operated on with a prediagnosis of penile fracture and then diagnosed with a false penile fracture. Material and Methods: Data of 8 patients who were diagnosed with a false penile fracture between January 2006 and September 2019 were retrospectively analyzed. Patients' demographic characteristics, preoperative, intraoperative and postoperative data were retrospectively analyzed.

Results: Mean age of the patients was 39.12 (28-54) years. The most common complaints were penile swelling and ecchymosis. The most common etiological factors were as follows: sexual intercourse in 6 , masturbation in 1 , and manual bending of the erect penis in 1 patient. All operations were performed by degloving the penis from the circumcision line. Superficial dorsal vein injury was detected in 6 , and nonspecific dartos bleeding was detected in 2 patients. There were no intraoperative complications. Wound site infection developed in 1 patient postoperatively. No erectile dysfunction, penile curvature, and sensory disturbances were detected in any patient.

Conclusion: It is difficult to distinguish a false penile fracture from true penile fracture clinically or radiologically. False penile fracture can be treated conservatively without the need for surgery. Surgery should still be the first-line treatment option in suspected patients. Studies with larger patient series are needed on this subject.
\end{abstract}

Keywords: superficial dorsal penile vein, false penile fracture, penile fracture, tunika albuginea

Öz

Amaç: Penil fraktür erken cerrahi müdahale gerektiren ürolojik acillerden biridir. Yalancı penil fraktür ise benzer klinik özelliklerle prezente olan konservatif olarak tedavi edilebilen bir durumdur. Bu çalışmada penil fraktür ön tanısı ile opere edilen ve yalancı penil fraktür tanısı konulan 8 hastanın klinik ve operatif sonuçlarının literatür eşliğinde sunulması amaçlandı.

Gereç ve Yöntemler: Ocak 2006 ve Eylül 2019 tarihleri arasında yalancı penil fraktür tanısı alan 8 hastanın verileri retrospektif olarak incelendi. Hastaların demografik özellikleri, operasyon öncesi, intraoperatif ve postoperatif verileri retrospektif olarak değerlendirildi.

Bulgular: Hastaların ortalama yaşı 39.12 (28-54) yıl idi. En sık başvuru şikayeti peniste şişlik ve morarmaydı. En sık saptanan etyolojik faktör 6 hastada cinsel ilişki, 1 hastada mastürbasyon, 1 hastada penisin ereksiyonda bükülmesiydi. Tüm operasyonlar sirkümsizyon hattından penisin deglove edilmesi ile yapıldı. 6 hastada yüzeysel dorsal ven yaralanması, 2 hastada ise nonspesifik dartos kanaması tespit edildi. İntraoperatif bir komplikasyon saptanmadı. Operasyon sonrası 1 hastada yara yeri enfeksiyonu gelişti. Hiç bir hastada erektil disfonksiyon, penil kurvatür ve his bozukluğu saptanmadı.

Sonuç: Yalancı penil fraktürün gerçek penil fraktürden klinik veya radyolojik olarak kesin olarak ayırt etmek zordur. Yalancı penil fraktür cerrahi gereksinimi olmadan konservatif olarak tedavi edilebilir. Şüpheli hastalarda cerrahi halen ilk basamak tedavi olmalıdır. Bu konuda daha fazla sayıda hasta serileri ile yapılacak çalışmalara ihtiyaç vardır.

Anahtar Kelimeler: yüzeyel dorsal penil ven, yalancı penil fraktür, penil fraktür, tunica albuginea $\begin{array}{lll}\text { ORCID: } & \text { K.G. Seker } 0000-0003-4449-9037 & \text { E. Sam 0000-0001-7706-465X } \\ & \text { Y.C. Seker } 0000-0002-3809-9398 & \text { E. Sam 0000-0002-2305-0794 }\end{array}$
Y. Arikan 0000-0003-0823-7400

F. Akkas $0000-0002-4560-7426$
J. Huseynov 0000-0002-9100-8723

N. Kalfazade 0000-0001-5734-8583 


\section{Introduction}

A true penile fracture is the occurrence of a tunical tear as a result of blunt trauma to the penis, usually during sexual intercourse or masturbation. It is an emergency that requires timely repair of the tear in the tunica albuginea. Otherwise, there may be consequences such as erectile dysfunction, chronic pain, corporal fibrosis and penile curvature in the long term [1]

In some patients, no tear is observed in the tunica albuginea during surgery. There may be penile ecchymosis or hematoma secondary to the rupture of the superficial veins of the penis. This condition is called a false penile fracture and amounts to $5-52 \%$ of clinically diagnosed penile fractures [2].

The characteristic symptoms of a penile fracture include ecchymosis and swelling of the penile body following a cracking sound, penile pain, and immediate detumescence [3]. However, history and physical examination can be inaccurate in $15 \%$ of patients with suspected penile fracture [4]. Preoperative detection of false penile fracture cases bears great importance. In these cases, morbidity can be avoided by refraining from performing unnecessary surgical interventions, and successful results can be obtained conservatively.

In this study, in the light of the literature, it was aimed to present the clinical and operative results of 8 patients who were operated on with a prediagnosis of penile fracture and then diagnosed with a false penile fracture in the light of the literature.

\section{Materials and Methods}

Local ethics committee approval was obtained prior to study (Approval Number: 2020/525). Out of 101 patients operated with a prediagnosis of penile fracture between January 2006 and September 2019, the medical records of $8(7.9 \%)$ patients who were diagnosed with a false penile fracture after the examination of the operative reports were evaluated retrospectively. The diagnosis of false penile fracture was made based on the detection of injury to the artery, vein, ligament and nonspecific dartos structures that caused bleeding other than the tear in the corpus cavernosum during surgical exploration. Stab injuries to the penis were excluded. Patients who had a tunical tear detected on preoperative magnetic resonance imaging (MRI), but surgical exploration did not reveal a tunical tear were considered as having false penile fracture. Patients' demographic characteristics (age, etiologic factors), clinical symptoms, physical examination, and radiological findings, intraoperative and postoperative data were recorded.

All patients were urgently operated. Acircumcision line incision was preferred in all surgical operations. After the evacuation of hematoma, tunical leakage was evaluated by establishing an artificial erection with intracorporal saline injection. The 2.0 and 3.0 absorbable sutures were preferred for ligation of arteries and veins causing bleeding. Urethral 16Fr-18Fr Foley catheters were inserted in all patients following the operation and then removed on postoperative day one. For dressing, Coban ${ }^{\mathrm{TM}}$ self-adhesive wraps were applied to all patients and removed on postoperative day three. Sexual intercourse and masturbation were banned for 6 weeks postoperatively. The patients were evaluated in terms of postoperative history, physical examination, erectile function and cosmetic appearance. History of erectile dysfunction (ED), medical treatment for ED, penile deformity, curvature, fibrotic nodules and penile sensation were questioned and evaluated. This study was carried out in accordance with the ethical principles of the Declaration of Helsinki after local ethics committee approval was obtained. Written informed consent was obtained from all patients participating in the study.

\section{Statistical Analysis}

All statistical analyses were performed with SPSS 22.0 version (SPSS Inc, Chicago, IL) package program. While evaluating the research data, descriptive statistical methods (mean, frequency, and ratio) were used.

\section{Results}

The mean age of the patients was 39.12 (28-54) years. All patients' physical examination findings revealed penile swelling and ecchymosis, and two patients had suprapubic and scrotal ecchymosis in addition to the penile region. The eggplant deformity was present in only one patient during the penile examination of the patients with false penile fractures. In one patient, the complaint of cracking sound and gradual tumescence was prominent. The causes of false penile fractures were sexual intercourse in $6(75 \%)$ masturbation in $1(12.5 \%)$ and manual bending of the penis in $1(12.5 \%)$ patient. The average time interval until surgery was $7.25(2-24)$ hours. None of the patients had urethral injury. Superficial dorsal vein injury was detected in $6(75 \%)$, and nonspecific dartos bleeding in $2(25 \%)$ patients. False positivity was detected in one of the two patients who underwent preoperative MRI. There were no complications in any patient intraoperatively. One patient developed an infection at the incision line postoperatively. The patient was treated with local and systemic antibiotherapy (Table 1).

Erectile dysfunction was not observed in any of the patients during the one-year postoperative follow-up. None of the patients had penile curvature, pain, palpable stiffness, cosmetic impairment or impaired urinary bladder functions.

\section{Discussion}

In true penile fracture, patients report that they heard a cracking sound and accompanying pain during sexual activity, and then detumescence occurs. In the physical examination, edema and hematoma are observed in a wide area, and "eggplant deformity" can be seen with the deviation of the penis towards the opposite side of the fracture. Although false penile fractures are clinically similar to the true penile fracture, there are some nonspecific distinctive conditions as: the absence of sudden cracking sound, and tunical defect; gradual detumescence and post-traumatic erection [5-7]. In our series, all patients had ecchymosis and one patient had a cracking sound during intercourse. Gradual detumescence was present in one patient.

A study investigating the role of cracking sound in the distinction between false penile fracture and true penile fracture 


\begin{tabular}{|c|c|c|c|c|c|c|c|c|}
\hline 苞 & 芩 & 苂 & ஜ̃ & 芩 & ż & : & 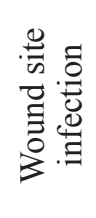 & $\begin{array}{l}\mathscr{0} \\
z\end{array}$ \\
\hline סิ & 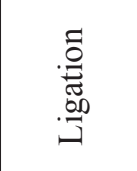 & 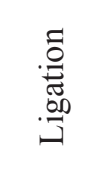 & 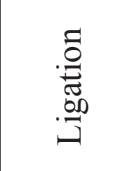 & 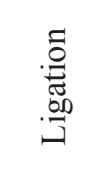 & 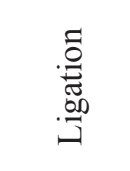 & 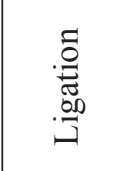 & . & 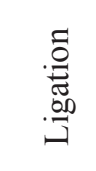 \\
\hline 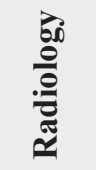 & 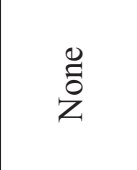 & 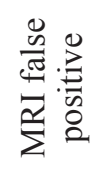 & 芩 & 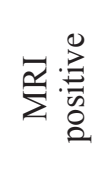 & 芩 & 芩 & 芩 & $\begin{array}{l}\mathscr{E} \\
z\end{array}$ \\
\hline 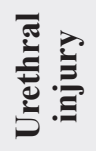 & 苂 & 苂 & 苂 & ह̃ & ह̃ & ह̃ & ह̃ & 芩 \\
\hline$\stackrel{\Xi}{\Xi}$ & 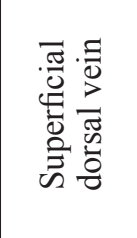 & 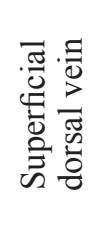 & 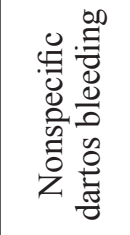 & 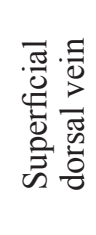 & 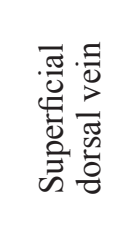 & 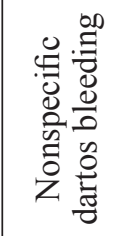 & 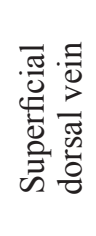 & 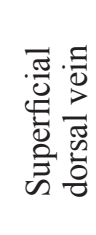 \\
\hline 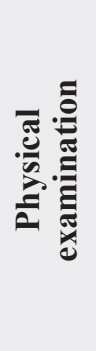 & 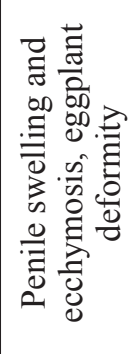 & 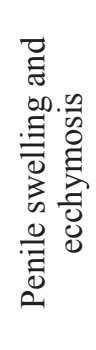 & 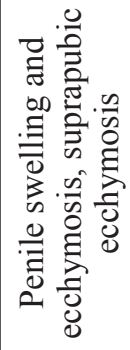 & 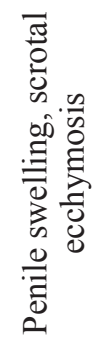 & 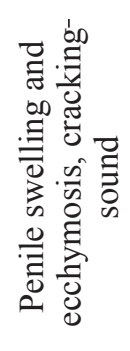 & 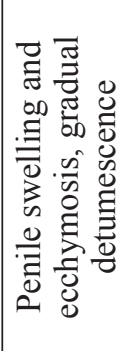 & 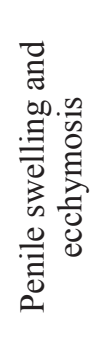 & 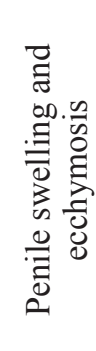 \\
\hline 㻤 & 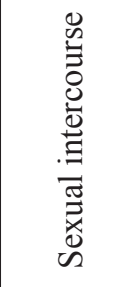 & 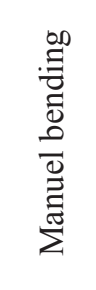 & 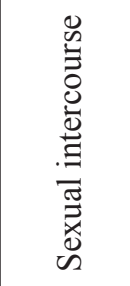 & 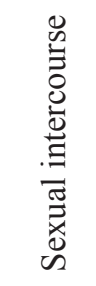 & 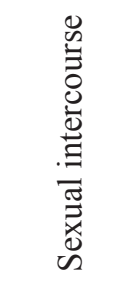 & 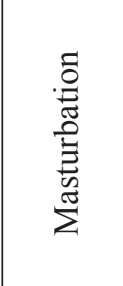 & 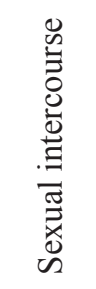 & 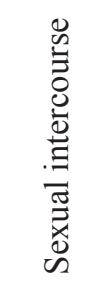 \\
\hline 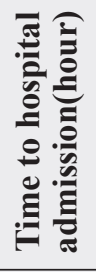 & $m$ & $n$ & 6 & in & $r$ & 0 & $\sim$ & $\stackrel{+}{\sim}$ \\
\hline 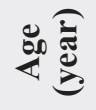 & 芯 & f & $\stackrel{\infty}{\sim}$ & $\hat{n}$ & ) & $\stackrel{\vartheta}{f}$ & $\stackrel{\sim}{\sim}$ & $\tilde{m}$ \\
\hline & - & $N$ & $m$ & $\nabla$ & in & 6 & $r$ & $\infty$ \\
\hline
\end{tabular}


among 65 consecutive clinically diagnosed penile fracture patients, true penile fractures were detected in 56 patients $(86.2 \%)$ and the cracking sound was present in most patients $(n=40,71.4 \%)$. Two of the nine patients with false fractures reported the cracking sound (22.2\%). Bayesian logistic regression revealed that the cracking sound was associated with surgical diagnosis of penile fracture (relative odds ratio $=4.25$ ), and the probability of penile fracture fell from 92 to $74 \%$ when the cracking sound was not reported among patients injured during intercourse experiencing immediate detumescence [2]. In our series, only one patient reported a cracking sound during sexual intercourse.

The shape and spread of ecchymosis can help to distinguish false penile fracture from true penile fracture. In cases with false penile fractures, the bleeding results from superficial dorsal penile vein rupture [8], deep dorsal vein rupture [9], dorsal artery avulsion/injury, and nonspecific dartos bleeding [10]. Feki et al. examined a series of 16 patients who underwent surgical penile exploration and detected nonspecific dartos bleeding in 16 and superficial dorsal vein avulsion requiring venous ligation in 6 cases [6]. In the series of Kurkar et al., superficial dorsal vein injury was observed in all patients [11]. El-Assmy et al. examined a series of 17 patients and detected that the bleeding resulted from an avulsed superficial dorsal vein in 5 out of 14 patients who underwent surgery. Nonspecific dartos bleeding was observed in the remaining 9 patients [12]. In our series, the most commonly injured vascular structure was the superficial dorsal vein.

The deep dorsal artery and vein are located under the Buck's fascia, so hematomas due to penile fracture and penile dorsal vein rupture are limited to space under this fascia. As long as the Buck's fascia remains intact, the hematoma is also confined to the shaft of the penis. The superficial dorsal vein is outside of the Buck's fascia and the hematoma due to its rupture will not be limited by the fascia $[13,14]$. If ecchymosis involves the scrotum, perineum, or pubic area, there may be due to two causes; false penile fracture due to superficial dorsal vein rupture or true penile fracture accompanying rupture of the Buck's fascia [15]. In our series, two patients had ecchymosis spreading to the suprapubic region and scrotum due to superficial vein injury.

In the literature, an intact corpus cavernosum was found between $2.7 \%$ and $10.7 \%$ of the patients who were operated for penile fracture. In our study, the rate of false penile fracture was found $7.9 \%$, which was consistent with the literature $[6,12,16]$.

Coherent with the literature, in our series the most common etiology was injury during sexual intercourse [6,11,12,17]. In the series of Feki et al., the etiology of nine patients was sexual intercourse, while other etiological factors included manual manipulation of the penis, trauma, rolling from bed and masturbation [6]. Kurkar et al. examined a penile fracture series of 68 patients and reported the etiology in 9 of 11 patients who underwent negative exploration as sexual intercourse and in 2 patients as masturbation [11]. In our series, other etiological factors included masturbation and manual bending of the erectile penis.

Various studies assessed radiological imaging methods in addition to physical examination and anamnesis in order to avoid unnecessary surgery in the differentiation between true and false penile fractures. The utility of imaging modalities is controversial in case of suspected penile fractures. Various imaging modalities have been used, such as MRI, retrograde urethrography (RUG), cavernosography, and ultrasonography (US). However, no specific radiological imaging method is routinely applied. The radiological imaging methods mentioned involve a number of advantages and disadvantages. In this regard, the penile US stands out in terms of its ease of use and cost-effectiveness. Two penile US findings are described in the definitive diagnosis of penile fracture as discontinuity of the tunica albuginea and/ or intracavernosal hematoma or the appearance of "Turkish eye sign". Metzler et al. emphasized the importance of using the penile US and the appearance of "Turkish eye sign" in addition to anamnesis and physical examination [18]. El-Assmy et al., in their series of 17 patients, detected intact tunica albuginea in 3 preoperative patients using imaging methods and eliminated surgical exploration [12]. In our series, no imaging method was used in any patient, except MRI in two patients.

Differentiation between true and false penile fractures is still one of the challenges in urology. General inclination is towards surgical exploration. Feki et al. concluded that surgery is still the only option for differential diagnosis [6]. Similarly, Kurkar et al. recommended surgical exploration to avoid long-term complications of overlooked tunica albuginea tears, due to the absence of reliable, rapid and practical imaging, although there is little clinical difference between these two conditions. The authors reported that evacuation of the hematoma and repair of possible dorsal penile vascular injury with early surgery will provide advantages with fewer complication rates even if a false penile fracture is in question [11]. Contrary to these views, Polat et al. stated that conservative approach would be sufficient in the treatment of false penile fractures [19].

Conservative treatment of patients with penile ecchymosis or hematoma without penile fracture involves application of ice, non-steroidal anti-inflammatory medications in the absence of contraindications, and compression with a loosely-applied compressive dressing, replaced daily, for 1-2 weeks to prevent further bleeding from the ruptured vessels, and 4 weeks of sexual abstinence [18]. Early surgical exploration, evacuation of the hematoma and ligation of the bleeding vessel lead to satisfactory results and preservation of potency in most patients with venous injury. In our series, surgery was performed in all patients and ligation of bleeding vessels was achieved.

Various complications were reported following penile surgery. In the series of Feki et al., localized ecchymosis of the glans that developed during the 2-week follow-up in one patient resolved spontaneously [6]. In the series of Kurkar et al., penile hypoesthesia was observed in one patient [11]. No complications were observed in the series of El-Assmy and Polat et al [12,19]. In our series, a skin infection developed in the penile circumcision line in one case.

Our study has some limitations. Firstly, it is a retrospective study. Secondly, it includes a small number of patients. The absence of patients treated conservatively can be considered another limitation.

\section{Conclusion}

Until a diagnostic tool is available, a reliable test to distinguish between false and true penile fractures should be the first-line treatment. Studies with larger patient series are needed on this subject. 
Ethics Committee Approval: The study was approved by University of Health Sciences, Dr. Sadi Konuk Training and Research Hospital Ethical Committee, Bakirkoy, Istanbul, Turkey (Decision No: 2020/525).

Informed Consent: An informed consent was obtained from all the patients.

Publication: The results of the study were not published elsewhere in full or in part in the form of abstracts.

Peer-review: Externally peer-reviewed.

Authorship Contributions: Any contribution was not made by any individual not listed as an author. Concept - D.N.O., K.G.S., E.S., Y.A.; Design - D.N.O., K.G.S., E.S., Y.A.; Supervision - D.N.O., K.G.S., J.H., N.K.; Resources - D.N.O., K.G.S., J.H., Y.C.S.; Materials - D.N.O., K.G.S., J.H., Y.C.S.; Data Collection and/or Processing - D.N.O., K.G.S., J.H., Y.C.S.; Analysis and/or Interpretation - D.N.O., K.G.S., J.H., Y.C.S., E.S., F.A.; Literature Search - D.N.O., K.G.S., J.H., Y.C.S., E.S., F.A.; Writing- D.N.O., K.G.S., J.H., Y.C.S., E.S., F.A.; Critical Review - D.N.O., K.G.S., J.H., N.K

Conflict of Interest: The authors declare that they have no conflict of interest.

Financial Disclosure: The authors have declared that they did not receive any financial support for the realization of this study. Informing: Due to the presence of the name of the journal assistant editor's among the authors, the assessment process of the study was conducted by the guest editor.

\section{References}

[1] De Luca F, Garaffa G, Falcone M, Raheem A, Zacharakis E, Shabbir M, et al. Functional outcomes following immediate repair of penile fracture: a tertiary referral centre experience with 76 consecutive patients. Scand J Urol 2017;51:170-5. https://doi.org/10.1080/21681805.2017.1280532.

[2] Dias-Filho AC, Fregonesi A, Martinez CAT, Pimentel ES, Riccetto CLZ. Can the snapping sound discriminate true from false penile fractures? Bayesian analysis of a case series of consecutively treated penile fracture patients. Int J Impot Res 2020;32:446-54. https://doi.org/10.1038/s41443-019-0199-7.

[3] McAninch JW, Santucci RA. Genitourinary Trauma. In: Walsh PC, Retik AB, Vaughan ED, Wein AJ, editors. Campbell's Urol. 8th ed., Philadelphia: Saunders; 2002, p. 3707-44.

[4] Beysel M, Tekin A, Gürdal M, Yüceba E, Dengör F. Evaluation and treatment of penile fractures: Accuracy of clinical diagnosis and the value of corpus cavernosography. Urology 2002;60:492-6. https://doi.org/10.1016/S0090-4295(02)01813-7.

[5] Armenakas NA, Hochberg DA, Fracchia JA. Traumatic avulsion of the dorsal penile artery mimicking a penile fracture. J Urol 2001;166:619. https://doi.org/10.1016/S0022-5347(05)66005-3.

[6] Feki W, Derouiche A, Belhaj K, Ouni A, Ben Mouelhi S, Ben Slama MR, et al. False penile fracture: Report of 16 cases. Int J Impot Res 2007;19:471-3.

https://doi.org/10.1038/sj.ijir.3901574.
[7] Pereira AP, Fentes DP, Caamaño VT, Parra MB, Parrado LV, González. MC. Rupture of the superficial vein of penis: therapeutic options. Arch Esp Urol 2010;63:871-3. https://doi.org/10.4321/s0004-06142010001000007.

[8] Koifman L, Barros R, Jnior RAS, Cavalcanti AG, Favorito LA. Penile fracture: Diagnosis, treatment and outcomes of 150 patients. Urology 2010;76:1488-92.

https://doi.org/10.1016/j.urology.2010.05.043.

[9] Polo EH, Garrigós JM, Ruiz MP, Tendero PT, Marcos MS. Penile hematoma caused by deep dorsal vein rupture during intercourse. Arch Esp Urol 2000;53:473-5.

[10] Shah DK, Paul EM, Meyersfield SA, Schoor RA. False fracture of the penis. Urology 2003;61:1259. https://doi.org/10.1016/S0090-4295(03)00106-7.

[11] Kurkar A, Elderwy AA, Orabi H. False fracture of the penis: Different pathology but similar clinical presentation and management. Urol Ann 2014;6:23-6.

https://doi.org/10.4103/0974-7796.127015.

[12] El-Assmy A, El-Tholoth HS, Abou-El-Ghar ME, Mohsen T, Ibrahiem EHI. False Penile Fracture: Value of Different Diagnostic Approaches and Long-term Outcome of Conservative and Surgical Management. Urology 2010;75:1353-6.

https://doi.org/10.1016/j.urology.2009.11.086.

[13] Chung KW. Gross Anatomy. 5th ed. Philadelphia: Lippincott Williams and Wilkins; 2005.

[14] Nicely ER, Costabile RA, Moul JW. Rupture of the deep dorsal vein of the penis during sexual intercourse. J Urol 1992;147:150-2. https://doi.org/10.1016/S0022-5347(17)37168-9.

[15] El-Sherif AE, Dauleh M, Allowneh N, Vijayan P. Management of Fracture of the Penis in Qatar. Br J Urol 1991;68:622-5.

https://doi.org/10.1111/j.1464-410X.1991.tb15427.x.

[16] Zargooshi J. Sexual function and tunica albuginea wound healing following penile fracture: An 18-year follow-up study of 352 patients from Kermanshah, Iran. J Sex Med 2009;6:1141-50. https://doi.org/10.1111/j.1743-6109.2008.01117.x.

[17] Bar-Yosef Y, Greenstein A, Beri A, Lidawi G, Matzkin H, Chen J. Dorsal vein injuries observed during penile exploration for suspected penile fracture. J Sex Med 2007;4:1142-6. https://doi.org/10.1111/j.1743-6109.2006.00347.x.

[18] Metzler IS, Reed-Maldonado AB, Lue TF. Suspected penile fracture: To operate or not to operate? Transl Androl Urol 2017;6:981-6. https://doi.org/10.21037/tau.2017.07.25.

[19] Polat H, Lök U, Gülactı U. Penile Fracture and False Penile Fracture: Is The Surgical Treatment Always Necessary? J Clin Exp Investig 2017;7:174-7. https://doi.org/10.5799/ahinjs.01.2016.02.0592. 